\title{
The Comparison of Semen Collection in Electroejaculation, Rectal Massage and Combination of Both Methods in the Critically Endangered Malayan Pangolin, Manis javanica
}

\author{
Reza Tarmizi ${ }^{1}$, Yap Keng Chee ${ }^{1}$, Symphorosa Sipangkui ${ }^{2}$, Zainal Zahari Zainuddin ${ }^{1}$ (I) \\ and Wan-Nor Fitri ${ }^{3, *(1)}$ \\ 1 Borneo Rhino Alliance, Sabah, Malaysia, c/o Faculty of Sciences and Natural Resources, \\ Universiti Malaysia Sabah, Kota Kinabalu 88400, Sabah, Malaysia; reza2727@gmail.com (R.T.); \\ kcyap.vet.upm@gmail.com (Y.K.C.); zainalz.bora@gmail.com (Z.Z.Z.) \\ 2 Sabah Wildlife Department, Tingkat 4, Blok B, Wisma MUIS, Kota Kinabalu 88100, Sabah, Malaysia; \\ symphorosa.sipangkui@sabah.gov.my \\ 3 Theriogenology and Cytogenetics Laboratory, Department of Veterinary Clinical Studies, Faculty of \\ Veterinary Medicine, Universiti Putra Malaysia (UPM), Seri Kembangan 43400, Selangor, Malaysia \\ * Correspondence: wannorfitri@upm.edu.my; Tel.: +06-8609-3908
}

Received: 21 August 2020; Accepted: 2 October 2020; Published: 23 October 2020

Simple Summary: Semen collection is one of the first few foundational steps towards Assisted Reproductive Technology (ART), however it is rarely conducted in the Malayan pangolin, Manis javanica. Semen was successfully retrieved in pangolins mainly via electroejaculation with the animal under general anesthesia, though facing a minor risk of urine contamination. The objective of this study is to report the success of semen collection with three different collection methods: electroejaculation, rectal massage and a combination of both methods in pangolins. The semen characteristics of the species are described in this study and the good semen qualities suggest future potential uses for ART. This study has found no difference between methods of semen collection. Captive and confiscated animals only differed in the percentages of live spermatozoa with overall good semen characteristics. The results from this study suggest that gamete recovery and biobank are feasible in the Malayan pangolin, which is essential to the management and conservation of this endangered species.

\begin{abstract}
This article describes the semen characteristics from different collection methods between captive and confiscated Malayan pangolins, Manis javanica. Semen was collected from 15 pangolins; two captive and 13 confiscated individuals at the mean weight of $9.36 \pm 1.94 \mathrm{~kg}$. The three semen collection methods employed were electroejaculation, rectal massage and a combination of both techniques. The semen characteristics (mean \pm standard deviation) of the Malayan pangolin are volume $(73.75 \pm 144.57 \mu \mathrm{L}), \mathrm{pH}(7.63 \pm 0.53)$, spermatozoa concentration $\left(997.19 \pm 728.98 \times 10^{6} / \mathrm{mL}\right)$, total motility $(59.60 \% \pm 30.00 \%)$, progressive motility $(48.95 \% \pm 30.93 \%)$, mass motility $(3.50 \pm 1.50)$ and live spermatozoa $(80.25 \% \pm 13.45 \%)$. There was no significant difference in semen characteristics between the three collection methods. The percentages of live spermatozoa were significantly different, suggesting better samples from captive compared to confiscated animals. However, there was no significant difference in spermatozoa kinetics between the captive and confiscated samples, suggesting the potential of utilizing confiscated individuals for gamete recovery to conserve the genetic pool of pangolins. All three methods of semen collection were successfully performed in pangolins and should be considered; however, electroejaculation remains the most consistent method of obtaining semen from the species.
\end{abstract}


Keywords: biobank; wildlife; illegal wildlife trade; assisted reproductive technology

\section{Introduction}

The Malayan pangolin (Manis javanica) is a critically endangered scaly anteater, with a home range in South East Asia. This nocturnal mammal, belonging to the order Pholidota, is one of the eight extant species of pangolins, and is closely related to the order Carnivora [1,2]. The population of Malayan pangolins in Peninsular Malaysia and throughout the islands of Borneo is severely under the threat of local extinction due to the illegal wildlife trade [3]. The trend of poaching activities is also concerning, with an estimated 192,567 pangolins seized between 1999 and 2017 [4]. Despite making the headlines during the recent coronavirus outbreak COVID-19 [5], pangolins are still being trafficked and the demand is still on the rise, as evidenced by the recent pangolins raid in Malaysia [6]. The critically endangered status of the Malayan pangolin and the increasing number of confiscated individuals suggest the need for a review of the ex-situ management program. The sudden increase in the availability of genetic reserve makes it necessary to consider the development of a gamete storage technique, and to increase the capacity of biobanking.

The effort of establishing assisted reproductive technology (ART) in Malayan pangolins is still at its infancy, despite being listed as critically endangered, at par with the Malayan tiger and Sumatran rhinoceros [7], the latter facing extinction in Malaysia recently [8]. The breeding and conservation of the species are of the utmost priority, since the three Malayan pangolin lineages are different and should be managed as distinct conservation units [9]. One of the best available tools to maximize the breeding of wildlife in ex situ conservation is ART [10]. However, it is integral to collate fundamental reproductive data to develop the right set of tools for the application of ART [11]. Semen collection and evaluation is one of the earlier required techniques to be established in pangolins, both for breeding soundness evaluation and ART development. Therefore, it is important to evaluate the reproductive health and establish good semen collection techniques for the future captive breeding program of the species.

The reproductive behavior [12] and the success of captive breeding in the Malayan pangolin have been reported [13]. The reproductive biology in male Malayan pangolins has also been explored recently $[14,15]$. The success of breeding the species in captivity suggests that the standard of husbandry and fertility of pangolins in captivity are satisfactory. However, the effect of acute and prolonged stress from poaching on the reproduction and fertility of pangolins is still being questioned [16]. Captive pangolins are not meant for domestication [17], however confiscated individuals were kept in captivity because of the challenges of reintroducing the pangolins back into the wild [18]. Several thousand pangolins are affected by the illegal wildlife trade [19], and semen collection will improve utilization and gamete banking through ART. Reproduction has been outlined, together with artificial habitat, nutritional [20] and disease control, as the main challenges for the captive breeding program in pangolins [21]. Yet studies on reproductive biology and ART in pangolins are still scarce. The technique of ART in wildlife tends to be species-specific due to each species' unique reproductive anatomy and physiology [22], making it urgent to take advantage of the confiscated individuals in a specific reproductive study of the Malayan pangolin.

Optimum semen collection methods are important to ensure success in ART. Various semen collection methods were described in wildlife, and innovation in semen collection is still being discovered [23], although many techniques have been adapted from domestic animals [10]. Yet the application, knowledge and success in different species varies, which suggests the need for a species-specific investigation. Semen collection by electroejaculation used to be the only means of achieving semen collection in wildlife and untrained animals. This highlights the importance of adding variation to the technique of semen collection by reducing the electrical stimulant given to the animal [24]. Reproductive health may be an important secondary welfare indicator [25] that perhaps 
is more sensitive than initially thought in pangolins. This article reports successful semen collection using electroejaculation, rectal massage and a combination of both in captive and confiscated Malayan pangolins on the island of Borneo.

\section{Materials and Methods}

\subsection{Animals}

There were 15 male pangolins involved in this study - 2 captive and 13 confiscated pangolins. All 15 pangolins were originally confiscated from the illegal wildlife trade. The pangolins which were considered as the captive group were the animals under the care of the Lok Kawi Wildlife Park. The two captive pangolins were acclimatized in a habitat made for pangolins within the wildlife park for 3 months before the semen collection procedure took place between August 2018 and January 2019. The remaining 13 confiscated pangolins were from two batches of raided specimens from two areas of Sabah, which were Tamparuli and Keningau, in February of 2019. Semen collections were performed on the confiscated group once approved by the Sabah Wildlife Department (SWD), within a week of confiscation. The minimum body weight criteria to be considered as sexually mature and clinically fit were being above $7 \mathrm{~kg}$ with a good body condition score. The mean body weight of all the pangolins was $9.36 \pm 1.94 \mathrm{~kg}$. The semen collection procedure was always overseen by veterinarians from SWD and Borneo Rhino Alliance (BORA), and this research was approved by the Wildlife Department under the approval code JHL(HQ)400-9/82 JLD 9.

\subsection{Semen Collection}

Semen was collected from all 15 individual pangolins, constituting 20 collection attempts using the three methods of semen collection: electroejaculation, rectal massage and a combination of electroejaculation and rectal massage. The semen collection was attempted in confiscated pangolins $(N=13)$ and in captive pangolins $(N=2)$; twice and five attempts in each animal respectively (Table 1$)$. The pangolins were all generally anaesthetized with a combination of (MKB) Medetomidine (Dorbene vet $1 \mathrm{mg} / \mathrm{mL}$, Zoetis), Ketamine (Ketamil 100mg/mL, Ilium) and Butorphanol (S6 50mg/mL, Kyron), all given intramuscularly at the dosage of $0.1 \mathrm{mg} / \mathrm{kg}, 5 \mathrm{mg} / \mathrm{kg}$ and $0.1 \mathrm{mg} / \mathrm{kg}$, respectively. At the end of the procedure, all the animals were given an antidote of Atipamezole (Atipamezole, $5 \mathrm{mg} / \mathrm{mL}$, Ilium), intramuscularly five times the dose of Medetomidine, and Naltrexone (S4 40mg/mL, Kyron), intramuscularly two times the dose of Butorphanol.

The semen collection methods were performed according to this order: (1) rectal massage, (2) electroejaculator and (3) combination of both methods. The success of semen collection during the rectal massage, manual feces evacuation and probe placement prevent the continual attempt of the following second and third methods. In an event whereby the semen was not obtained by rectal massage, the electroejaculator procedure followed. Semen was considered as obtained by electroejaculator when ejaculates were acquired during electrical stimulation. Finally, semen was considered as obtained by a combination of both methods when the ejaculates were acquired between the electroejaculator cycle, when the rectal massage was performed with no electrical stimulation applied. The flow of the semen collection procedure is simplified in Figure 1. Following the three-step semen collection protocol, the attempts were made 17 times with the electroejaculator, twice with the rectal massage and once with the combination of both methods.

The semen collection procedure was preceded by the evacuation of feces and the placement of the rectal probe using a Seager Model 14 electro-ejaculator (Dalzell USA Medical Systems, The Plains, VA, USA), equipped with $1.0 \mathrm{~cm}$ diameter rectal probe. During the rectal manipulation, the flow of semen can be observed occasionally from the penile opening, thus the procedure was followed by the massaging of the ventral rectal wall. The digital massage of the rectal wall (rectal massage) was accompanied by a gentle massage of the ventral abdomen in a craniocaudal motion towards the accessory glands and vas deferens to facilitate the flow of semen. Following the rectal and abdominal 
massages, the electroejaculation method was followed up in four cycles until the collection ended, starting from 3 volts up to a maximum of 7 volts in a total of 4 stimulations, with 10 cycles for each stimulation. The rectal and abdominal massage was performed between the electrical stimulation.

Table 1. Semen collection details of individual pangolins.

\begin{tabular}{|c|c|c|c|c|c|c|c|}
\hline \multirow[t]{2}{*}{ No. } & \multirow[t]{2}{*}{ Pangolin ID } & \multirow[t]{2}{*}{ Location } & \multirow[t]{2}{*}{ Captive } & \multirow[t]{2}{*}{ Confiscated } & \multicolumn{3}{|c|}{ Collection Attempts } \\
\hline & & & & & $\mathbf{R M}$ & EE & $\mathrm{EE}+\mathrm{RM}$ \\
\hline 1. & 000728DD97 & Lok Kawi Wildlife Park & • & & & 2 & \\
\hline 2. & 00074FD17F & Lok Kawi Wildlife Park & $\bullet$ & & 2 & 2 & 1 \\
\hline 3. & EX1 & Tamparuli & & o & & 1 & \\
\hline 4. & EX2 & Tamparuli & & o & & 1 & \\
\hline 5. & EX3 & Tamparuli & & o & & 1 & \\
\hline 6. & EX4 & Tamparuli & & o & & 1 & \\
\hline 7. & EX5 & Tamparuli & & 0 & & 1 & \\
\hline 8. & EX6 & Tamparuli & & o & & 1 & \\
\hline 9. & EX7 & Tamparuli & & o & & 1 & \\
\hline 10. & JG1 & Keningau & & o & & 1 & \\
\hline 11. & JG2 & Keningau & & o & & 1 & \\
\hline 12. & JG3 & Keningau & & o & & 1 & \\
\hline 13. & JG4 & Keningau & & 0 & & 1 & \\
\hline 14. & JG5 & Keningau & & 0 & & 1 & \\
\hline 15. & JG6 & Keningau & & o & & 1 & \\
\hline
\end{tabular}

RM: rectal massage, EE: electroejaculator.

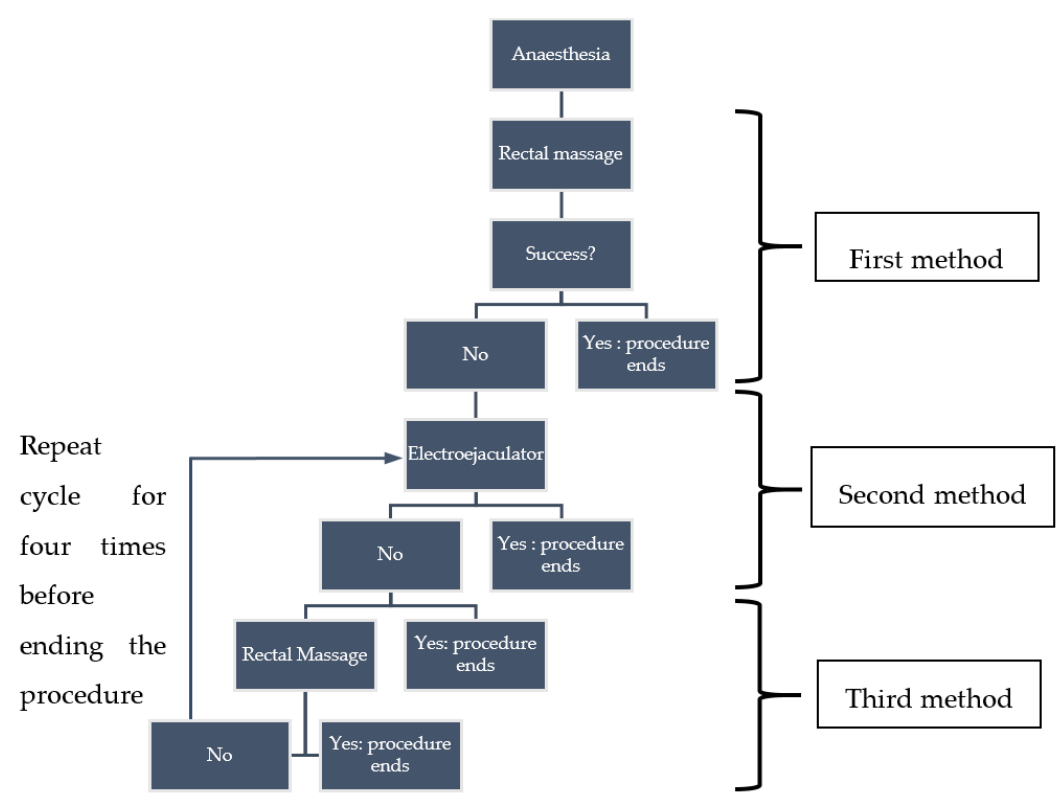

Figure 1. Pangolin semen collection flow and methods. Success in each initial method prevents the continuation of further semen collection methods until the procedure ends at the fourth cycle of electrical stimulation.

\subsection{Semen Evaluation}

The semen characteristics evaluation was mainly based on a standard in pangolins [26]. However, the standard parameters for semen description were slightly modified based on standards established in domestic animals and wildlife [27-29]. Semen volume was estimated based on the droplets of semen, each droplet with the size of $0.5 \mathrm{~mm}$ in diameter to be averaged at $15 \mu \mathrm{L} /$ drop. Semen concentration was determined using a Neubaeur haemocytometer counting chamber (VWR International, Lutterworth, Leicestershire, UK) [30]. Semen was maintained in a water bath at $37.5^{\circ} \mathrm{C}$ before semen motility 
assessment. Total motility and progressive motility were estimated under a phase-contrast microscope at 400x magnification (Olympus Corporation, Tokyo, Japan) under x40 objective, by two experienced veterinary laboratory technicians, blinded on the condition of the animals and independent of each other in order to obtain an unbiased evaluation and an average value of the sperm motility. The mass motility in pangolins were established based on standards in domestic animals [31,32]. Semen was also subjected to live-dead analysis, diluted with one-part semen and three-part Eosin Nigrosin stain and thin-smeared on a glass slide. The $\mathrm{pH}$ of semen was determined by using $\mathrm{pH}$ strips as an indication for urine contamination (Whatman ${ }^{\circledR} \mathrm{pH}$ indicator paper strip, Marlborough, MA, USA).

\subsection{Statistical Analysis}

The ejaculates collected were subjected to analysis using the statistical package IBM SPSS Statistics 20 , and values were reported as mean \pm standard deviation. Analysis of variance was used to identify a significant difference between ejaculates from different individuals, rejected and accepted samples, collection methods, and between captive and confiscated pangolins at $p<0.05$. Frequency distribution tables were also used to obtain and report on the efficiency of the methods used.

\section{Results}

The consistency of semen in pangolins is sticky, slimy, thick and creamy, and appears white to a slight hue of a yellowish tinge. Semen was successfully collected in all three methods 17/20 times $(85 \%)$, by electroejaculator $2 / 20$ times $(10 \%)$, and by rectal massage $1 / 20$ times $(5 \%)$ in the combination methods. A minute semen volume $(73.75 \pm 144.57 \mu \mathrm{L})$, which was highly concentrated $(997.19 \pm 728.98$ $\left.\times 10^{6} / \mathrm{mL}\right)$ and had moderate total motility $(59.60 \pm 30.00)$, progressive motility $(48.95 \pm 30.93)$ and mass motility $(3.50 \pm 1.50)$, as well as a high live spermatozoa count $(80.25 \pm 13.45)$, was observed in pangolins.

There was no significant difference between individual animals, thus semen characteristics were pooled. Mean semen characteristics between the urine-contaminated and urine-free samples were reported in Table 2. The high volume of ejaculates showed results of a mixture with urine; $660 \mu \mathrm{L}$ and $200 \mu \mathrm{L}$, low spermatozoa concentrations of $381.25 \times 10^{6} / \mathrm{mL}$ and $100 \times 10^{6} / \mathrm{mL}$, a lower pH of 6.25 and zero spermatozoa motility in this study was confirmatory of urine contamination in the two collection attempts using an electroejaculator. The semen characteristics between different collections are reported in Table 3. However, there was no significant difference between semen collection methods. Semen collection by rectal massage and a combination of methods was successfully attempted in captive populations only, meanwhile the use of an electroejaculator was necessary for all the confiscated population. The semen characteristics of captive and confiscated pangolins are reported in Table 4, with a significant difference between the live percentages of spermatozoa. 
Table 2. Mean semen characteristics in urine-contaminated and urine-free samples in pangolins.

\begin{tabular}{|c|c|c|c|}
\hline \multirow{2}{*}{ Semen Characteristics } & \multirow{2}{*}{ Mean \pm SD $(n=20)$} & \multicolumn{2}{|c|}{ Mean Semen Characteristics } \\
\hline & & Urine Contaminated $(n=2)$ & Urine Free $(n=18)$ \\
\hline Volume $(\mu \mathrm{L})$ & $\begin{array}{l}73.75 \pm 144.57 \\
(5.00-660.00)\end{array}$ & $\begin{array}{c}430.00 \pm 325.27^{\mathrm{a}} \\
(200.00-660.00)\end{array}$ & $\begin{array}{c}34.17 \pm 23.34^{\mathrm{b}} \\
(5.00-90.00)\end{array}$ \\
\hline $\mathrm{pH}$ & $\begin{array}{l}7.63 \pm 0.53 \\
(6.25-8.00)\end{array}$ & $6.25 \pm 0.00^{a}(6.25)$ & $\begin{array}{c}7.78 \pm 0.26^{b} \\
(7.50-8.00)\end{array}$ \\
\hline $\begin{array}{l}\text { Spermatozoa concentration } \\
\qquad\left(\times 10^{6} / \mathrm{mL}\right)\end{array}$ & $\begin{array}{c}997.19 \pm 728.98 \\
(100.00-2541.00)\end{array}$ & $\begin{array}{l}240.63 \pm 198.87 \\
(100.00-381.25)\end{array}$ & $\begin{array}{l}1081.25 \pm 718.87 \\
(107.50-2541.00)\end{array}$ \\
\hline Total motility (\%) & $\begin{array}{c}59.60 \pm 30.00 \\
(0.00-90.00)\end{array}$ & $0.00 \pm 0.00^{\mathrm{a}}(0.00)$ & $\begin{array}{c}66.22 \pm 23.27^{\mathrm{b}} \\
(15.00-90.00)\end{array}$ \\
\hline Progressive motility (\%) & $\begin{array}{c}48.95 \pm 30.93 \\
(0.00-90.00)\end{array}$ & $0.00 \pm 0.00^{\mathrm{a}}(0.00)$ & $\begin{array}{c}54.39 \pm 27.50^{\mathrm{b}} \\
(7.00-90.00)\end{array}$ \\
\hline Mass motility (0-5) & $\begin{array}{l}3.50 \pm 1.50 \\
(0.00-5.00)\end{array}$ & $0.00 \pm 0.00^{\mathrm{a}}(0.00)$ & $\begin{array}{c}3.89 \pm 0.96^{\mathrm{b}} \\
(2.00-5.00)\end{array}$ \\
\hline Live spermatozoa (\%) & $\begin{array}{l}80.25 \pm 13.45 \\
(36.10-97.50)\end{array}$ & $92.50 \pm 0.71(92.00-93.00)$ & $\begin{array}{l}78.89 \pm 13.51 \\
(36.10-97.50)\end{array}$ \\
\hline
\end{tabular}

Values are mean \pm SD (ranges). Different superscripts between column differ significantly, $p<0.05$.

Table 3. Mean semen characteristics between different collection methods in pangolins.

\begin{tabular}{cccc}
\hline & \multicolumn{3}{c}{ Mean Semen Characteristics } \\
\cline { 2 - 4 } Semen Characteristics & $\begin{array}{c}\text { Rectal Massage } \\
(\boldsymbol{n}=\mathbf{2})\end{array}$ & $\begin{array}{c}\text { Electroejaculator } \\
(\boldsymbol{n}=\mathbf{1 7})\end{array}$ & $\begin{array}{c}\text { Combination } \\
(\boldsymbol{n}=\mathbf{1})\end{array}$ \\
\hline Volume $(\mu \mathrm{L})$ & $42.50 \pm 3.54(40.00-45.00)$ & $80.00 \pm 156.63(5.00-660.00)$ & 30.00 \\
pH & $7.50 \pm 0.00(7.50)$ & $7.65 \pm 0.57(6.25-8.00)$ & 7.50 \\
Spermatozoa & $1247.95 \pm 38.25$ & $944.73 \pm 781.44(100.00-2541.00)$ & 1387.50 \\
concentration $\left(\times 10^{6} / \mathrm{mL}\right)$ & $(1220.90-1275.00)$ & $54.82 \pm 30.05(0.00-90.00)$ & 80.00 \\
Total motility $(\%)$ & $90.00 \pm 0.00(90.00)$ & $43.47 \pm 30.19(0.00-90.00)$ & 70.00 \\
Progressive motility $(\%)$ & $85.00 \pm 7.07(80.00-90.00)$ & $3.24 \pm 1.48(0.00-5.00)$ & 5.00 \\
Mass motility $(0-5)$ & $5.00 \pm 0.00(5.00)$ & $78.27 \pm 13.55(36.10-93.00)$ & 88.00 \\
Live spermatozoa $(\%)$ & $93.20 \pm 6.08$ & 85 & 5 \\
Collection success $(\%)$ & 10 & & \\
\hline
\end{tabular}

Table 4. Mean semen characteristics in captive and confiscated pangolins.

\begin{tabular}{ccc}
\hline \multirow{2}{*}{ Semen Characteristics } & \multicolumn{2}{c}{ Mean Semen Characteristics in Captive or Confiscated Animal } \\
\cline { 2 - 3 } & Captive $(\boldsymbol{n}=7)$ & Confiscated $(\boldsymbol{n}=\mathbf{1 3})$ \\
\hline Volume $(\mu \mathrm{L})$ & $134.29 \pm 232.06(30.00-660.00)$ & $41.15 \pm 53.63(5.00-200.00)$ \\
$\mathrm{pH}$ & $7.32 \pm 0.47(6.25-7.50)$ & $7.79 \pm 0.50(6.25-8.00)$ \\
Spermatozoa concentration $\left(\times 10^{6} / \mathrm{mL}\right)$ & $995.38 \pm 426.39(381.25-1387.50)$ & $998.16 \pm 866.30(100.00-2541.00)$ \\
Total motility $(\%)$ & $65.00 \pm 33.54(0.00-90.00)$ & $56.69 \pm 28.92(0.00-90.00)$ \\
Progressive motility $(\%)$ & $59.29 \pm 34.45(0.00-90.00)$ & $43.38 \pm 28.74(0.00-80.00)$ \\
Mass motility $(0-5)$ & $3.86 \pm 1.86(0.00-5.00)$ & $3.31 \pm 1.32(0.00-5.00)$ \\
Live spermatozoa $(\%)$ & $89.94 \pm 4.52^{\mathrm{a}}(82.70-97.50)$ & $75.03 \pm 13.85^{\mathrm{b}}(36.10-93.00)$ \\
\hline
\end{tabular}

Values are mean \pm SD (ranges). Different superscripts between column differ significantly, $p<0.05$.

\section{Discussion}

The first known attempts at semen collection, describing the different methods of collection and semen characteristics in pangolins, are reported in this study. There were reports of spermatozoa morphology in pangolins $[15,26,33,34]$, yet semen collection and the characteristics within the genus, species and order remain to be elucidated. The pangolins are closely related phylogenetically with the order of Carnivora [35], prompting a potential comparison across the order due to the lack of available data. Although some semen characteristics in pangolins were similar when compared to the wild felid [36], the semen volume, concentration and viability appeared to be different. In contrast, the semen 
characteristics in brown bears seemed to be superior in terms of total motility [37]. The comparison of semen characteristics across distinct species, due to physically different anatomies, physiologies and the sheer size alone, could explain the variation, especially in the semen volume. Thus, it was suggested to conduct the study of semen characteristics in a species-specific manner in order to overcome the differences and specific challenges to ART application [38]. It is also understood that a comparison of semen characteristics even between the most closely related orders, Pholidota and Carnivora, fell short in many ways, highlighting the importance of this study to the reproductive knowledge of pangolins.

Pangolin semen characteristics are suitable for future work in ART. The semen has a thick and slimy consistency, which does not take well to being aspirated with single-channel micropipette fitted with micropipette tips (0.5-10 $\mu$ L, Eppendorf Research ${ }^{\circledR}$ plus G, single-channel, medium grey epT.I.P.S $\left.{ }^{\circledR}\right)$. Thus, the method of estimating semen droplets with highly viscous ejaculates using droplets size was the best option in the field to estimate the semen volume after using a mechanical micropipette in wildlife [39]. There are various factors related to the success of artificial insemination in wildlife. Spermatozoa kinetics is deemed one of the factors which is important for the outcome of fertility [40]. The semen kinetics (total motility, progressive motility and mass motility) in pangolins are good, though faced with the challenge of the minute volume of semen yield, the ejaculates can further be extended using a semen extender. There is high potential in using ART in pangolins with the current semen quality, as attempts in ART with even lower semen parameters were found to be successful for in wildlife [41]. Artificial insemination is yet to be performed in pangolins; however, successful captive breeding in pangolins suggests that the animals fare well in captivity, and captive breeding is possible [21].

The overall information on semen collection and reproductive biology in pangolins is limited. The efficiency between the three collection methods still proves that the electroejaculator remains the most consistent method to obtain semen from the species. The small sample size in this study limits the explanation of the observed three methods of semen collection in the captive populations. However, the experience of semen collection via rectal massage and the combination of rectal massage and electroejaculator usage suggests that these two methods are also possible in pangolins. These findings offer further physiological and welfare understanding of the effects of the illegal wildlife trade on reproduction, although stressors are known to affect reproduction in wildlife [42]. Digital massage alone has been a successful tool in collecting semen from various species of wildlife, such as crocodiles, Bali cattle and endangered nonhuman primates [43-45]. In this study, general anesthesia provides better welfare to the animal as it is painless and less stressful [46]. Apart from that, the drug also has an alpha-adrenergic effect on the smooth muscle involved with semen release, allowing the flow of semen in the reproductive tract to the penile tip [47]. The findings were similar in the use of anesthesia in other wild mammals, using the xylazine combination under general anesthesia, in which the semen can sometimes be collected readily on the penile tip with the manipulation and positioning of the electroejaculator probe as an effect of immobilization [48]. However, it was found that medetomidine has 10 times more specificity towards the alpha-2-receptors than xylazine, indicating medetomidine as the better drug for spermatozoa recovery [49]. Digital massage of the rectal for semen collection in the sedated animals was also observed in other wildlife, together with the aid of gravitational pull through the positioning of the animal on a raised platform [50]. Semen collection by electroejaculator usage poses the risk of urine contamination, as observed in this study. Although electorejaculator usage was consistent in yielding semen in pangolins, the methods are known to carry the risk of urine contamination in other mammals [51,52]. Urine contamination can also be reflective in the increased volume of ejaculates due to urine contamination, the decreased $\mathrm{pH}$ and motility of the spermatozoa [53], the occurrence of zero spermatozoa motility as well as the $\mathrm{pH}$ reduction in the two samples derived in our case. The higher live spermatozoa count in urine-contaminated samples compared with urine-free samples suggests that the initial quality of semen collected from urine-contaminated samples could potentially be better. However, this potential was greatly reduced due to urine contamination. After the urine-contaminated samples were removed, the semen characteristics of pangolins showed improved 
kinetic motilities and better live spermatozoa counts. The results from this study propose that it would be possible and promising to cryopreserved pangolin semen for future use in ART.

The important factors of reproduction between captive and confiscated animals are health and stress. Confiscated pangolins are known to be heavily infested with parasites, inflicted with multiple traumatic wounds related to transport and handling, as well as hunger-associated complications [54]. These lesions are associated with survival more than reproductive potential, especially when considering a release program. However, the long-term impacts of poaching were observed to pose an impact on the stress physiology and reproductive output in female African elephants [55]. These observations could likely be reproducible in pangolins, and the effect would be more immediate given the shorter lifespan. This study suggests that the difference in semen characteristics is in the live spermatozoa percentage between the captive and confiscated animals. Health evaluation of the confiscated animal is of the utmost importance to the welfare of the animal, and has been described in detail in pangolins [56]. The reproductive status may be an indirect indicator of the wellbeing of pangolins in captivity, similar to other captive mammals [56]. The minor difference in semen quality in captive and confiscated pangolins suggests that it can adapt well in captivity, given the right husbandry. Semen collection for the potential use of gamete storage and cryopreservation in the confiscated individuals was also shown to be possible. Therefore, semen collection should be considered as part of a routine procedure to improve conservation efforts in the Malayan pangolin.

\section{Conclusions}

Semen collection attempts were successful using electroejaculation, rectal massage and a combination of rectal massage and electroejaculation in pangolins. Electroejaculator usage remains the most consistent method of semen collection, however success in rectal massaging and the combination of both methods is proposed to be possible and advantageous in the species. The semen quality is better in the captive compared to the confiscated animals, however without any difference in the spermatozoa's kinetics. The success of semen collection for gamete storage and cryopreservation in confiscated individuals in this study suggests that the procedure should be considered as part of routine practice to improve the conservation effort in this species.

Author Contributions: Formal analysis, W.-N.F.; investigation, R.T.; writing-review and editing, Y.K.C.; supervision, Z.Z.Z.; project administration, S.S. All authors have read and agreed to the published version of the manuscript.

Funding: This research is funded by the federal government of Malaysia.

Acknowledgments: The authors gratefully acknowledge the staff at Lok Kawi Wildlife Park and Borneo Rhino Alliance for their assistance throughout the procedures.

Conflicts of Interest: The authors declare no conflict of interest.

\section{References}

1. Du Toit, Z.; Du Plessis, M.; Dalton, D.L.; Jansen, R.; Paul Grobler, J.; Kotzé, A. Mitochondrial genomes of African pangolins and insights into evolutionary patterns and phylogeny of the family Manidae. BMC Genomics 2017, 18, 746. [CrossRef] [PubMed]

2. Du Toit, Z.; Grobler, J.P.; Kotzé, A.; Jansen, R.; Brettschneider, H.; Dalton, D.L. The complete mitochondrial genome of Temminck's ground pangolin (Smutsia temminckii; Smuts, 1832) and phylogenetic position of the Pholidota (Weber, 1904). Gene 2014, 551, 49-54. [CrossRef] [PubMed]

3. Sompud, J.; Sompud, C.B.; Pei, K.J.; Sun, N.C.; Repin, R.; Tuh, F. Sunda Pangolin Manis javanica (Mammalia: Pholidota: Manidae) of Gaya Island, Sabah. J. Threat. Taxa 2019, 11, 13552-13556. [CrossRef]

4. Gomez, L.; Leupen, B.; Krishnasamy, K.; Heinrich, S. SCALY NEXUS: Mapping Indonesian Pangolin Seizures (2010-2015); TRAFFIC: Petaling Jaya, Malaysia, 2017.

5. Liao, Y.; Wei, W.; Cheung, W.Y.; Li, W.; Li, L.; Leung, G.M.; Holmes, E.C.; Hu, Y.; Guan, Y. Identifying SARS-CoV-2 related coronaviruses in Malayan pangolins. Nature 2020, 583, 282-285. 
6. Malaysian Customs Seizes Six Tonnes of African Pangolin Scales. Available online: https://www.maritimeexecutive.com/article/malaysian-customs-seize-six-tonnes-of-african-pangolin-scales (accessed on 1 June 2020).

7. PERHILITAN. Red List of Mammals for Peninsular Malaysia, 1st ed.; Red List of Mammals for Peninsular Malaysia: Kuala Lumpur, Malaysia, 2017; ISBN 9789675557194.

8. Bittel, J. Last Sumatran Rhino in Malaysia Dies. Available online: https://www.nationalgeographic.com/ animals/2019/05/last-sumatran-rhino-malaysia-dies/ (accessed on 1 June 2020).

9. Nash, H.; Wirdateti; Low, G.; Choo, S.; Chong, J.; Semiadi, G.; Hari, R.; Sulaiman, M.; Turvey, S.; Evans, T.; et al. Conservation genomics reveals possible illegal trade routes and admixture across pangolin lineages in Southeast Asia. Conserv. Genet. 2018, 19, 1083-1095. [CrossRef]

10. Holt, W.V.; Lloyd, R.E. Artificial insemination for the propagation of CANDES: The reality! Theriogenology 2009, 71, 228-235. [CrossRef]

11. Pukazhenthi, B.S.; Wildt, D.E. Which reproductive technologies are most relevant to studying, managing and conserving wildlife? Reprod. Fertil. Dev. 2004, 16, 33-46. [CrossRef]

12. Zhang, F.; Yu, Y.; Yu, J.; Wu, S.; Li, S.; Wang, Q.; Min, Y.; Sun, R. Reproductive behavior of the captive Sunda pangolin (Manis javanica Desmarest, 1822). Zoo Biol. 2020, 39, 65-72. [CrossRef]

13. Zhang, F.; Yu, J.; Wu, S.; Li, S.; Zou, C.; Wang, Q.; Sun, R. Keeping and breeding the rescued Sunda pangolins (Manis javanica) in captivity. Zoo Biol. 2017, 36, 387-396. [CrossRef]

14. Akmal, Y.; Nisa', C.; Novelina, S. Anatomy of the Male Reproductive Organs of Javan Pangolin (Manis javanica). In Proceedings of the 3 Joint International Meeting, Bogor, Indonesia, 13-15 October 2014; pp. 1-2.

15. Akmal, Y. Mahfud Spermatogenesis dan Histologi Testis Trenggiling Jantan (Manis javanica). Semdi Unaya 2019, 3, 563-575.

16. Alejandro, C.-I.; Abel, V.-M. Environmental Stress Effect on Animal Reproduction. Adv. Dairy Res. 2015, 2, 2-5. [CrossRef]

17. Banes, G.L.; Galdikas, B.M.F.; Vigilant, L. Reintroduction of confiscated and displaced mammals risks outbreeding and introgression in natural populations, as evidenced by orang-utans of divergent subspecies. Sci. Rep. 2016, 6, 1-9. [CrossRef] [PubMed]

18. Bovenkerk, B. Animal Ethics in the Age of Humans. In Animal Ethics in the Age of Humans; Bovenkerk, B., Keulartz, J., Eds.; Springer: Cham, Switzerland, 2016; Volume 23, pp. 151-171, ISBN 978-3-319-44205-1.

19. Cheng, W.; Xing, S.; Bonebrake, T.C. Recent Pangolin Seizures in China Reveal Priority Areas for Intervention. Conserv. Lett. 2017, 10, 757-764. [CrossRef]

20. Zhang, F.; Xu, N.; Yu, Y.; Wu, S.; Li, S.; Wang, W. Expression profile of the digestive enzymes of Manis javanica reveals its adaptation to diet specialization. ACS Omega 2019, 4, 19925-19933. [CrossRef] [PubMed]

21. Hua, L.; Gong, S.; Wang, F.; Li, W. Captive breeding of pangolins: Current status, problems and future prospects. Zookeys 2015, 507, 99-114. [CrossRef]

22. Andrabi, S.M.H.; Maxwell, W.M.C. A review on reproductive biotechnologies for conservation of endangered mammalian species. Anim. Reprod. Sci. 2007, 99, 223-243. [CrossRef]

23. Lueders, I.; Luther, I.; Scheepers, G.; van der Horst, G. Improved semen collection method for wild felids: Urethral catheterization yields high sperm quality in African lions (Panthera leo). Theriogenology 2012, 78, 696-701. [CrossRef]

24. Jiménez-Rabadán, P.; Ramón, M.; García-álvarez, O.; Maroto-Morales, A.; del Olmo, E.; Pérez-Guzmán, M.D.; Bisbal, A.; Fernández-Santos, M.R.; Garde, J.J.; Soler, A.J. Effect of semen collection method (artificial vagina vs. electroejaculation), extender and centrifugation on post-thaw sperm quality of Blanca-Celtibérica buck ejaculates. Anim. Reprod. Sci. 2012, 132, 88-95. [CrossRef]

25. Grimard, B.; de Boyer des Roches, A.; Coignard, M.; Lehébel, A.; Chuiton, A.; Mounier, L.; Veissier, I.; Guatteo, R.; Bareille, N. Relationships between welfare and reproductive performance in French dairy herds. Vet. J. 2019, 248, 1-7. [CrossRef]

26. Ballowitz, E. Die form und sffuktur der schuppelltierspermien. Zeit Wiss Zool 1907, 86, 619-624.

27. Salamon, S.; Maxwell, W.M.C. Storage of ram semen. Anim. Reprod. Sci. 2000, 62, 77-111. [CrossRef]

28. Soley, J.T. Light microscopic features and morphometry of sperm in the emu (Dromaius novaehollandiae). Theriogenology 2014, 81, 203-209. [CrossRef] 
29. Fitri, W.; Wahid, H.; Rinalfi, P.T.; Raj, D.; Donny, Y.; Qayyum, L.; Aziz, A.; Malek, A. Spermatozoa morphometry and ultrastructure in estuarine crocodile (Crocodylus porosus). Asian Pac. J. Reprod. 2020, 9, 104-108. [CrossRef]

30. Kirkman-Brown, J.; Björndahl, L. Evaluation of a disposable plastic Neubauer counting chamber for semen analysis. Fertil. Steril. 2009, 91, 627-631. [CrossRef]

31. Evans, G.; Maxwell, W.M.C. Salamon's Artificial Insemination of Sheep and Goats; Butterworths-Heinemann Ltd. 1987: Sydney, Australia, 1952.

32. Fitri, W.-N.; Wahid, H.; Rosnina, Y.; Jesse, F.F.A.; Aimi-Sarah, Z.A.; Mohd-Azmi, M.L.; Azlan, C.A.; Azrolharith, M.R.; Peter, I.D.; Baiee, F.H.A. Semen characteristics, extension, and cryopreservation of Rusa deer (Rusa timorensis). Vet. World 2017, 10, 779-785. [CrossRef]

33. Leung, L.; Cummins, J. Morphology of immature spermatozoa of the Chinese pangolin (manis P.entadactyla: Pholidota). Proc. Aust. Soc. Reprod. Biol. 1988, 20, 94.

34. Challender, D.; Nash, H.; Waterman, C. Pangolins Science Society and Conservation; Nyhus, P., Ed.; Elsevier: San Diego, CA, USA, 2019; ISBN 9780128022139.

35. Meredith, R.W.; Janec, J.E.; Gatesy, J.; Ryder, O.A.; Fisher, C.A.; Teeling, E.C.; Goodbla, A.; Eizirik, E.; Simão, T.L.L.; Stadler, T.; et al. Impacts of the Cretaceous terrestrial mammal diversification. Science 2011, 334, 521-524. [CrossRef]

36. Zainuddin, Z.Z.; Tarmizi, M.R.M.; Yap, K.C.; Pierre, C.; Sipangkui, S. First evaluations and cryopreservation of semen samples from sunda clouded leopards (Neofelis diardi). Animals 2020, 10, 1072. [CrossRef]

37. Chamorro, C.; Anel, L.; De Paz, P.; Borraga, S. Analysis of seminal plasma from brown bear (Ursus arctos) during the breeding season: Its relationship with testosterone levels. PLoS ONE 2017, 12, e0181776.

38. Morrow, C.J.; Penfold, L.M.; Wolfe, B.A. Artificial insemination in deer and non-domestic bovids. Theriogenology 2009, 71, 149-165. [CrossRef]

39. Wahid, H.; Ming, Y.; Zainal, Z.Z. Evaluation of semen collected by electroejaculation from captive lesser Malay chevrotain (Tragulus javanicus). Am. Assoc. Zoo Vet. 2000, 31, 164-167. [CrossRef]

40. Baiee, F.H.; Haron, A.W.A.W.; Yusoff, R.H.; Omar, M.A.; Yimer, N.; Jeber, Z.; Hammadi, S.; Ahmedeltayeb, T.; Fitri, W.-N.; Umar, M.; et al. Kinetic Motilities of Cryopreserved Bull Spermatozoa: Owing to the Effect of Eurycoma Longifolia Jack Aqueous Extract. Am. J. Anim. Vet. Sci. 2017, 12, 77-84. [CrossRef]

41. Pennington, P.M.; Diego, S.; Global, Z. Assisted reproductive technologies in captive rhinoceroses. Mamm. Rev. 2019, 49, 1-15. [CrossRef]

42. Baker, M.R.; Gobush, K.S.; Vynne, C.H. Review of factors influencing stress hormones in fish and wildlife. J. Nat. Conserv. 2013, 21, 309-318. [CrossRef]

43. Sarsaifi, K.; Rosnina, Y.; Ariff, M.; Wahid, H.; Hani, H.; Yimer, N.; Vejayan, J.; Win Naing, S.; Abas, M. Effect of semen collection methods on the quality of pre- and post-thawed bali cattle (bos javanicus) spermatozoa. Reprod. Domest. Anim. 2013, 48, 1006-1012. [CrossRef] [PubMed]

44. Fitri, W.-N.; Wahid, H.; Rinalfi, P.T.; Rosnina, Y.; Raj, D.; Donny, Y.; Qayyum, L.; Malek, A.A.A. Digital massage for semen collection, evaluation and extension in Malaysian estuarine crocodile (Crocodylus porosus). Aquaculture 2018, 483, 169-172. [CrossRef]

45. Schaffer, N.; Cranfield, M.; Meehan, T.; Kempske, S. Semen collection and analysis in the conservation of endangered nonhuman primates. Zoo Biol. 1989, 8, 47-60. [CrossRef]

46. Kirschner, S.M.; Rodenkirch, R. Assessment of butorphanol-azaperone-medetomidine combination as anesthesia for semen collection and evaluation of semen quality in white-tailed deer (Odocoileus virginianus). Anim. Reprod. Sci. 2017, 184, 196-203. [CrossRef]

47. Sousa, P.C.; Amorim, R.N.L.; Lima, G.L.; Paiva, A.L.C.; Paula, V.V.; Freitas, C.I.A.; Silva, A.R. Establishment of an anesthetic protocol for semen collection by electroejaculation in six-banded armadillos (Euphractus sexcinctus Linnaeus, 1758). Arq. Bras. Med. Vet. Zootec. 2016, 68, 1595-1601. [CrossRef]

48. Zambelli, D.; Prati, F.; Cunto, M.; Iacono, E.; Merlo, B. Quality and in vitro fertilizing ability of cryopreserved cat spermatozoa obtained by urethral catheterization after medetomidine administration. Theriogenology 2008, 69, 485-490. [CrossRef]

49. Swanson, W.F.; Bateman, H.L.; Vansandt, L.M. Urethral catheterization and sperm vitrification for simplified semen banking in felids. Reprod. Domest. Anim. 2017, 52, 255-260. [CrossRef] [PubMed] 
50. Johnston, S.D.; Lever, J.; Mcleod, R.; Oishi, M.; Qualischefski, E.; Omanga, C.; Leitner, M.; Price, R.; Barker, L.; Kamau, K.; et al. Semen collection and seminal characteristics of the Australian saltwater crocodile (Crocodylus porosus). Aquaculture 2014, 422-423, 25-35. [CrossRef]

51. Bertschinger, H.; Nothling, J.O.; Nardini, R.; Hemmelder, S.; Broekhuisen, M.H. Collection of semen in cheetahs (Acinonyx jubatus) using electro-ejaculation: Attemps to avoid urine contamination. Ethology 2002, $37,122$.

52. Crosier, A.E.; Wachter, B.; Schulman, M.; Luders, I.; Koester, D.; Wielebnowski, N.; Comizzoli, P.; Marker, L. Reproductive Physiology of the Cheetah and Assisted Reproductive Techniques. In Cheetahs: Biology and Conservation; Valutkevich, A., Ed.; Elsevier Inc.: London, UK, 2018; pp. 385-402, ISBN 9780128040881.

53. Fukui, D.; Nagano, M.; Nakamura, R.; Bando, G.; Nakata, S.; Kosuge, M.; Sakamoto, H.; Matsui, M.; Yanagawa, Y.; Takahashi, Y. The effects of frequent electroejaculation on the semen characteristics of a captive siberian tiger (Panthera tigris altaica). J. Reprod. Dev. 2013, 59, 491-495. [CrossRef]

54. Clark, L.; Thai, N.; Phoung, T. A long way from home: The health status of Asian Pangolins confiscated from the illegal wildlife trade in Viet Nam. In Proceedings of the Workshop on Trade and Conservation of Pangolins Native to South and Southeast Asia, Singapore Zoo, Singapore, 30 June-2 July 2009; Pantel, S., Chin, S., Eds.; Traffic: Petaling Jaya, Malaysia, 2009; pp. 111-118.

55. Gobush, K.S.; Mutayoba, B.M.; Wasser, S.K. Long-term impacts of poaching on relatedness, stress physiology, and reproductive output of adult female African elephants. Conserv. Biol. 2008, 22, 1590-1599. [CrossRef]

56. Ritter, C.; Beaver, A.; von Keyserlingk, M.A.G. The complex relationship between welfare and reproduction in cattle. Reprod. Domest. Anim. 2019, 54, 29-37. [CrossRef]

Publisher's Note: MDPI stays neutral with regard to jurisdictional claims in published maps and institutional affiliations. 